\title{
Groundwater chemistry and origin of the visutla delta plain
}

\author{
Arkadiusz Krawiec $^{1}$, Andrzej Sadurski ${ }^{1,2}$ \\ ${ }^{1}$ Nicolaus Copernicus University, Faculty of Earth Sciences, Toruń, Poland \\ ${ }^{2}$ Polish Polish Geological Institute NRI, Gdańsk, Poland
}

\begin{abstract}
River estuaries are peculiar areas from the point of view of their groundwater origins, frequently connected with the diversification of groundwater chemistry. In the area of the Vistula delta in a number of places, the increased concentration of chloride and fluoride ions has occurred (Kozerski et al. 1987). These issues have already been considered in the studies of Kozerski (1981), Kozerski and Kwaterkiewicz $(1984,1988)$. The origin of salt and brackish water in the area of Żuławy was already the subject of scientific research in the 1930s (Schroeder 1931), and subsequently continued by Sadurski (1985, 1989), Burzyński and Sadurski (1989), Zuber at al. (1990, 2000) and Krawiec (2013).
\end{abstract}

\section{INTRODUCTION}

The Vistula delta plain constitues a flat plain formed by the accumulation of alluvial deposits. The area of Vistla delta can be dividied into: Żuławy Gdańskie, Wielkie and Żuławy Elbląskie in its eastern part. Around 30\% of this region is below the sea level and this depression achieves the level of -1.8 metres above the sea level in the vicinity of Drużno Lake. The highland of the Kashubian Lake District forms the natural western border of the Vistula delta whereas the eastern border is formed by the Elblag Hills and the highland of the Iława Lake District (Fig.1). These highlands reach the altitude of over 200 metres above the sea level and were formed by the sediments of subsequent glaciations.

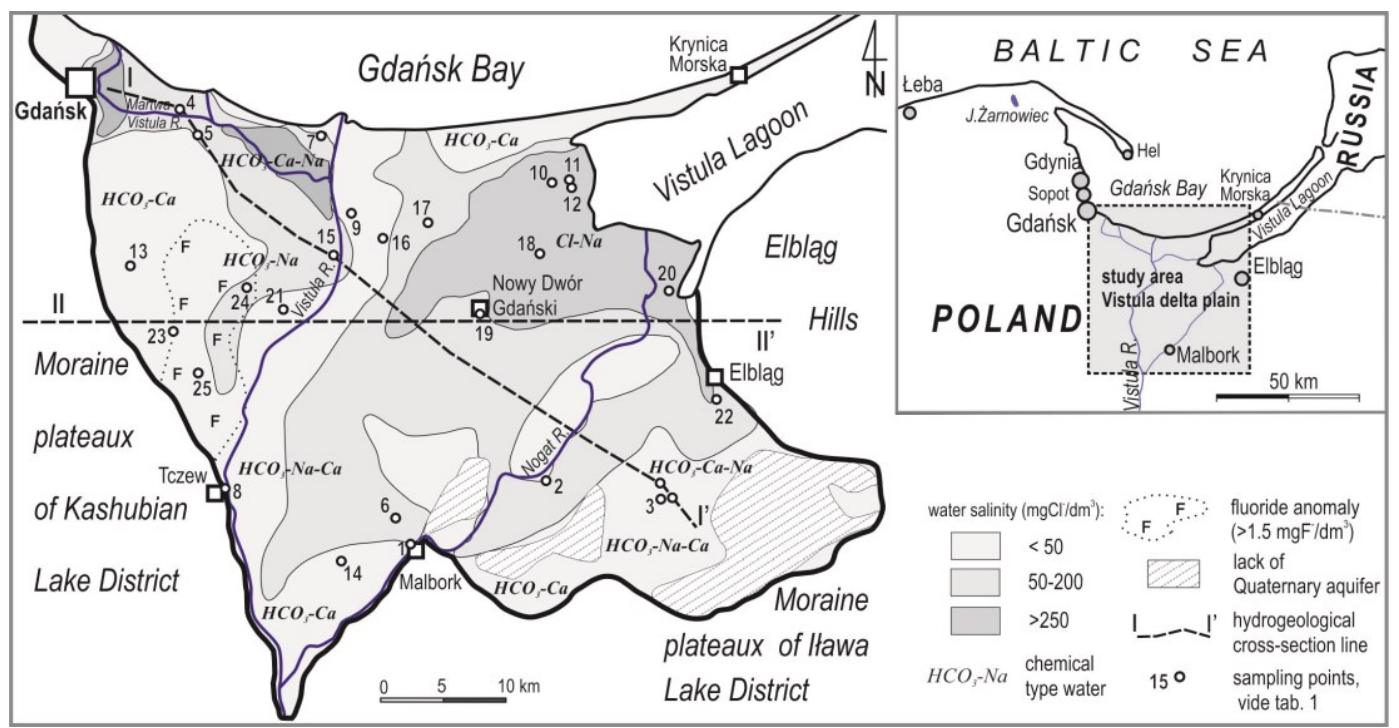

Figure 1. Location of study area and chloride and fluoride anomaly of the Vistula delta plane. 


\section{GEOLOGY AND HYDROGEOLOGY}

In the area of the Vistula delta there are the Pleistocene and Holocene sediments, which mainly consist of glacial till and interglacial limnic-fluvial sediments in the form of sands, loams and silts. The Holocene alluvia of the Vistula delta were formed as sands, loams, sludge and peats of fluvial and marine origin in their northern part (Fig. 2).

Under the deposits of the Cainozoic and Palaeozoic sedimentary cover of the Precambrian East European Platform can be found. On the bedrocks of the Quaternary strata there occur discontinuous sediments of the Neogene and the Palaeogene formed as glauconitic finegrained sands, occasionally with loam intercalations. In a large part of the Żuławy area these sediments were destroyed and on the surface of the sub-Quaternary period sand and marl sediments of the Upper Cretaceous. The sub-Quaternary surface bedrock is located at the elevation from -80 to $-120 \mathrm{~m}$ sea level (Fig. 2).

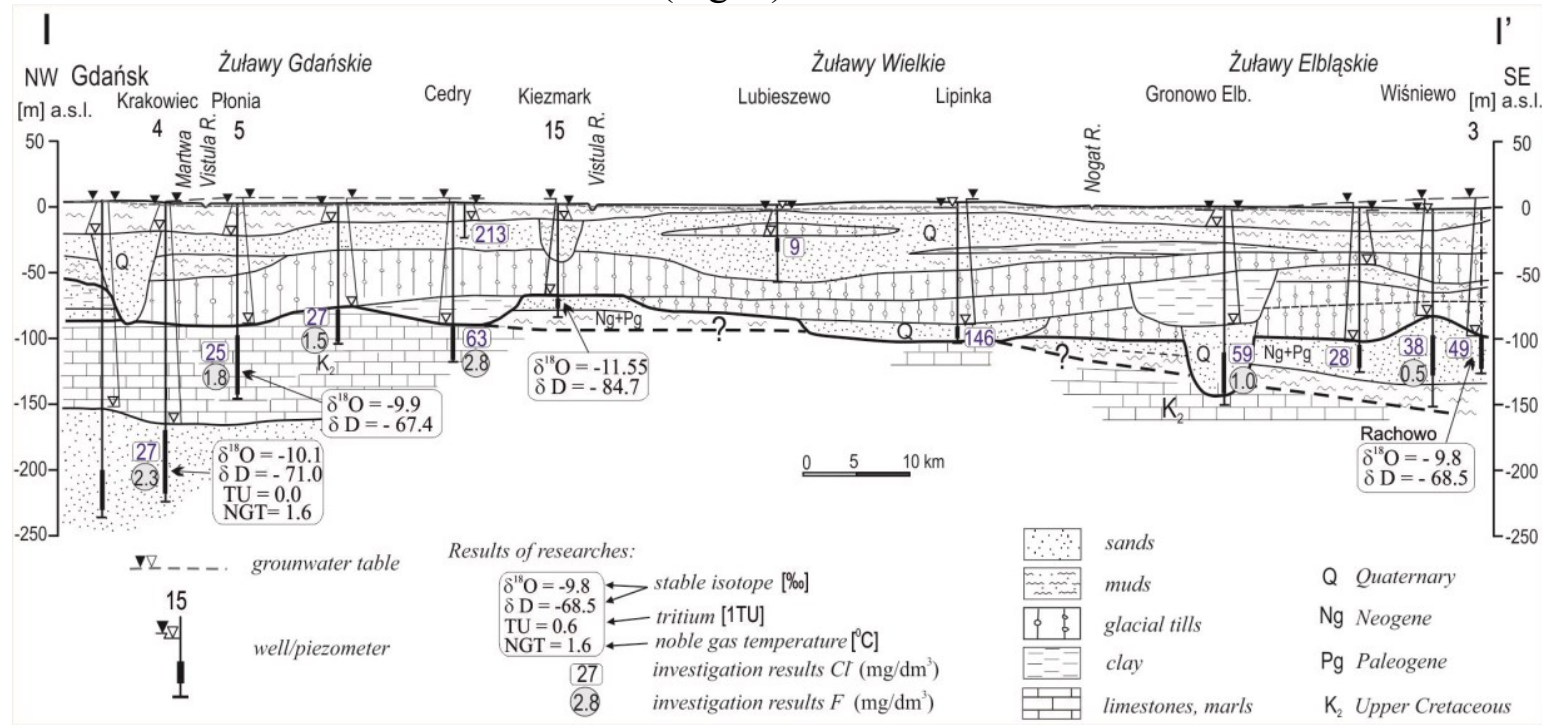

Figure 2. Hydrogeological cross-section I - I' in the Żulawy Wiślane area.

In the area under consideration there occurs multi-level aquifer, but the main utility significance can be ascribed to the Pleistocene aquifer, the so-called uneven-aged and Cretaceous sediments (Kozerski, Kwaterkiewicz 1988). The Pleistocene and Holocene aquifer commonly occurs in the area of Żuławy. The thickness of the deltaic Holocene aquifer hardly ever exceeds $20 \mathrm{~m}$. This aquifer is supplied by waters from the surrounding highlands as well as the ascension of waters from the deepest aquifer (Burzyński and Sadurski 1989; Zuber at al. 2000).The aquifers that are the most abundant in ground waters occur in the marginal zone of the western part of the Vistula delta - the drinking water intake for the city of Gdansk called „Lipce” and in the eastern part, in the vicinity of the Nogat River, where the municipal water intake called „Letniki” is situated.

The uneven-aged aquifers are formed of the earliest Quaternary entities, sand sediments of the Palaeogene and Neogene periods, and occasionally of the parts of surface bedrock of the Cretaceous (Sadurski 1989; Kozerski, Kwaterkiewicz 1988). This level is separated from the Pleistocene and Holocene level by a series of glacial till, and occasionally also loams and silts. It occurs in a large part of the Żuławy area, but its absence was reported in the northern part of Żuławy Gdańskie and Wielkie. The thickness of sand sediments of the uneven-aged complex most commonly ranges from 10 to $20 \mathrm{~m}$, and in the structures of buried valleys it can reach even 40 metres. 
The Cretaceous aquifer is connected with a series of carbonate formations at the roof and lower-lying sands with glauconite (Sadurski 1989). The waters connected with a series of carbonate and silica occur in the eastern parts of Żuławy Gdańskie and the southern part of Żuławy Wielkie. Żuławy Wiślane and the Gulf of Gdansk constitute the regional drainage base for groundwater flowing down from the surrounding lakeland elevations as well as from the Elbląg Hills.

Detailed model tests have demonstrated that the lateral inflow from the highlands ranges from around $60 \%$ of the balance total in the recreated "natural" conditions to $65 \%$ with the mandatory amount of water abstraction (Kulma et. al. 2002). The average rate of infiltration water recharge in the area of Żuławy does not exceed 1\% of annual precipitation level.

Anomalously high concentration of chloride and fluoride ions, as well as iron compounds are recorded both within the Quaternary and Cretaceous aquifers. In the marginal zones of Żuławy Wiślane, the groundwater of the Pleistocene and Holocene aquifers as well as that of the deeper uneven-aged level are both most frequently of the $\mathrm{HCO}_{3}-\mathrm{Ca}$ type. This is mainly freshwater. In the more distant areas from the upland edges, within the Quaternary aquifer of Vistula delta occur groundwater of the $\mathrm{HCO}_{3}-\mathrm{Ca}-\mathrm{Na}$ type can also be found. The admixtures of the so-called young relict waters of marine origin can also occur here, which results in changes in water chemistry to the $\mathrm{Cl}-\mathrm{HCO}_{3}-\mathrm{Na}$ type.

\section{RESULTS AND DISCUSSION}

The highest concentration of $\mathrm{Cl}^{-}$ions in the Pleistocene and Holocene aquifers has been recorded in the north-eastern part of Żuławy Wielkie and in the northern part of Żuławy Elbląskie (Fig. 1). The high concentration of chlorides, connected with brackish water ingression from surface watercourses, have also been recorded in the vicinity of Gdańsk (Kozerski, Kwaterkiewicz 1988),where the natural groundwater cycle was disrupted due to the launch of large municipal water intakes in the north-western part of Żuławy. On the Cretaceous aquifer in the area of Żuławy there occurs water of $\mathrm{HCO}_{3}-\mathrm{Na}$ and $\mathrm{Cl}-\mathrm{HCO}_{3}-\mathrm{Na}$ types (Kozerski and Kwaterkiewicz 1984; 1988; Sadurski 1985; 1989). In some parts of this area, for example in the north-eastern part of Żuławy, for instance, Gozdawa - tab.1, no 18, the water of Cl-Na type can also be found. In the area of Żuławy Gdańskie and the eastern and southern marginal zones of the Vistula delta there occurs freshwater (tab.1, no 4-9).

Table 1. Isotope and noble gas data from the Żuławy Wiślane area.

\begin{tabular}{|c|c|c|c|c|c|c|c|c|c|c|c|}
\hline No & $\begin{array}{l}\text { Sampling } \\
\text { strat./depth }\end{array}$ & Data & $\begin{array}{c}\mathrm{Cl}^{-} \\
{[\mathrm{mg} / \mathrm{l}]}\end{array}$ & $\begin{array}{l}\text { Tryt } \\
\text { (TU) }\end{array}$ & $\begin{array}{l}\delta^{18} 0(\%) \\
\text { V-SMOW }\end{array}$ & $\begin{array}{c}\delta^{2} \mathrm{H}(\%) \\
\text { V-SMOW }\end{array}$ & $\begin{array}{c}\delta^{13} \mathrm{C}(\% 0) \\
\text { V-PDB }\end{array}$ & $\begin{array}{c}{ }^{14} \mathrm{C} \\
(\mathrm{pMC})\end{array}$ & $\begin{array}{l}\text { NGT } \\
{\left[{ }^{0} \mathrm{C}\right]}\end{array}$ & $\begin{array}{c}{ }^{4} \mathrm{He}_{\text {excess }} \\
10^{-6} \mathrm{~cm}^{3} \mathrm{~g}^{-1}\end{array}$ & "age" water \\
\hline 1 & $\begin{array}{l}\text { Malbork } \\
\text { K/96-121 }\end{array}$ & $\begin{array}{l}1986 \\
1998\end{array}$ & 107 & $0.0 \pm 1.0$ & $\begin{array}{l}-8.8 \\
-9.0\end{array}$ & $\begin{array}{l}-63.0 \\
-64.0 \\
\end{array}$ & -5.2 & 4.5 & 0.2 & 1.3 & ${ }^{14} \mathrm{C}=12.7 \mathrm{ka}$ \\
\hline 2 & $\begin{array}{l}\text { Letniki K-1 } \\
\text { K/137-250 }\end{array}$ & $2000^{A}$ & & & -9.9 & -71.4 & -9.0 & 14.6 & & & ${ }^{14} \mathrm{C}=7.5 \mathrm{ka}$ \\
\hline 3 & $\begin{array}{l}\text { Rachowo } \\
\text { Tr/106-128 }\end{array}$ & $2000^{A}$ & 49 & & -9.8 & -68.5 & -12.0 & 18.7 & & & ${ }^{14} \mathrm{C}=7.8 \mathrm{ka}$ \\
\hline 4 & $\begin{array}{l}\text { Krakowiec } \\
\text { K/171-230 }\end{array}$ & \begin{tabular}{|l|}
1986 \\
1998
\end{tabular} & 27 & $0.0 \pm 1.0$ & $\begin{array}{l}10.0 \\
-10.1\end{array}$ & $\begin{array}{l}-67.0 \\
-71.0\end{array}$ & -7.0 & 2.1 & 1.6 & 0.681 & ${ }^{14} \mathrm{C}=21.5 \mathrm{ka}$ \\
\hline 5 & $\begin{array}{l}\text { Płonia M. } \\
\text { K/112-147 }\end{array}$ & $2000 \mathrm{~A}$ & & & -9.9 & -67.4 & -5.6 & 0.7 & & & ${ }^{14} \mathrm{C}=28.6 \mathrm{ka}$ \\
\hline 6 & $\begin{array}{l}\text { Kościelecz. } \\
\text { Q/64-76 }\end{array}$ & 1987 & 81 & $0.0 \pm 1.0$ & -9.7 & -68.0 & -6.8 & 13.1 & & & ${ }^{14} \mathrm{C}=7.1 \mathrm{ka}$ \\
\hline 7 & $\begin{array}{l}\text { Świbno K-2 } \\
\text { K/94-120 }\end{array}$ & 1998 & 27 & & -12.0 & -85.0 & & & 2.2 & 1.56 & $\begin{array}{l}\text { infiltr. in a cool } \\
\text { climate }\end{array}$ \\
\hline
\end{tabular}




\begin{tabular}{|c|c|c|c|c|c|c|c|c|c|c|c|}
\hline 8 & $\begin{array}{l}\text { Tczew. K-1 } \\
\text { K/160-180 }\end{array}$ & 1998 & 152 & $0.0 \pm 1.0$ & -9.4 & -66.0 & -8.0 & 14.0 & 4.2 & 0.941 & ${ }^{14} \mathrm{C}=6.9 \mathrm{ka}$ \\
\hline 9 & $\begin{array}{l}\text { Drewnica } \\
\text { K/96-130 }\end{array}$ & 1986 & 24 & $0.0 \pm 1.0$ & -12.1 & -85.0 & -6.0 & 1.7 & & & ${ }^{14} \mathrm{C}=22.9 \mathrm{ka}$ \\
\hline 10 & $\begin{array}{l}\text { Grochowo } \\
\text { K/120-150 }\end{array}$ & 2010 & & & -12.90 & -97.0 & & & & & $\begin{array}{l}\text { infiltr. in a coo } \\
\text { climate }\end{array}$ \\
\hline 11 & $\begin{array}{l}\text { Laszka } \\
\text { Q/2-5 }\end{array}$ & 2010 & 453 & $3.2 \pm 0.3$ & -8.89 & -68.5 & -7.6 & 77.3 & & & modern; \\
\hline 12 & \begin{tabular}{|l|} 
Łaszka \\
$\mathrm{Q} / 2.6-22$ \\
\end{tabular} & 1986 & 2600 & $0.7 \pm 1.0$ & -8.8 & -64.0 & +2.2 & 28.0 & & & holocene \\
\hline 13 & $\begin{array}{l}\text { Roszkowo } \\
\text { Q/87-106 }\end{array}$ & 1987 & 3 & $0.0 \pm 1.0$ & -10.0 & -66.0 & -6.6 & 6.7 & & & ${ }^{14} \mathrm{C}=12.4 \mathrm{ka}$ \\
\hline 14 & $\begin{array}{l}\text { Stara Koś. } \\
\text { Q/1.7-15 }\end{array}$ & 2010 & 86 & & -8.9 & -65.3 & & & & & holocene \\
\hline 15 & \begin{tabular}{|l|} 
Kiezmark \\
$\mathrm{Tr} / 71-83$ \\
\end{tabular} & $2000^{A}$ & 60 & & -11.55 & -84.7 & -6.6 & 2.0 & & & ${ }^{14} \mathrm{C}=21.3 \mathrm{ka}$ \\
\hline 16 & $\begin{array}{l}\text { Niedzwiedz } \\
\text { Q-K }\end{array}$ & 2010 & 202 & & -10.6 & -77.6 & & & & & $\begin{array}{l}\text { infiltr. in a coo } \\
\text { climate }\end{array}$ \\
\hline 17 & $\begin{array}{l}\text { Wiśniówka } \\
\text { Q-K }\end{array}$ & 2010 & 408 & $0.5 \pm 0.3$ & -10.14 & -76.1 & & & & & $\begin{array}{l}\text { infiltr. in a coo } \\
\text { climate }\end{array}$ \\
\hline 18 & $\begin{array}{l}\text { Gozdawa } \\
\text { K/94-115 }\end{array}$ & \begin{tabular}{|l|}
1986 \\
1998 \\
2010 \\
\end{tabular} & $\begin{array}{l}1287 \\
1830 \\
1554 \\
\end{array}$ & $\begin{array}{l}0.0 \pm 1.0 \\
0.4 \pm 0.3\end{array}$ & $\begin{array}{l}-10.8 \\
-11.0 \\
-10.9 \\
\end{array}$ & $\begin{array}{l}-79.0 \\
-80.0 \\
-82.0 \\
\end{array}$ & $\begin{array}{l}-3.4 \\
-4.5 \\
\end{array}$ & $\begin{array}{l}3.8 \\
1.1 \\
\end{array}$ & 3.5 & 8.24 & $\begin{array}{l}{ }^{14} \mathrm{C}=10.5 \mathrm{ka} \\
{ }^{14} \mathrm{C}=24.2 \mathrm{ka}\end{array}$ \\
\hline 19 & $\begin{array}{l}\text { N. Dw. Gd. } \\
\text { Q/21-36 }\end{array}$ & 2010 & 156 & & -8.47 & -62.7 & & & & & $\begin{array}{l}\text { holocene and } \\
\text { admix. of salt } \\
\text { water (older) }\end{array}$ \\
\hline 20 & $\begin{array}{l}\text { Nowakowo } \\
\text { K2/99-136 }\end{array}$ & 1987 & 632 & $0.3 \pm 1.0$ & -12.5 & -88.0 & -4.0 & 3.0 & & & ${ }^{14} \mathrm{C}=14.9 \mathrm{ka}$ \\
\hline 21 & $\begin{array}{l}\text { Długie Pole } \\
\text { K/188-235 } \\
\end{array}$ & $\begin{array}{l}1986 \\
1998 \\
\end{array}$ & $\begin{array}{l}525 \\
485\end{array}$ & $0.0 \pm 1.0$ & $\begin{array}{l}-10.0 \\
-10.1 \\
\end{array}$ & $\begin{array}{l}-70.0 \\
-72.0 \\
\end{array}$ & -4.9 & 1.8 & 0 & 2.18 & $19.7 \mathrm{ka}$ \\
\hline 22 & $\begin{array}{l}\text { Elblag. K-4 } \\
\text { ok. } 120 \mathrm{~m}\end{array}$ & $\begin{array}{l}1986 \\
1998 \\
\end{array}$ & 278 & $0.0 \pm 1.0$ & $\begin{array}{l}-11.1 \\
-11.2 \\
\end{array}$ & $\begin{array}{l}-78.0 \\
-81.0 \\
\end{array}$ & -7.4 & 8.0 & 3.8 & 10.4 & ${ }^{14} \mathrm{C}=10.8 \mathrm{ka}$ \\
\hline 23 & $\begin{array}{l}\text { Ostrowite } \\
\mathrm{Q} / 10-40\end{array}$ & 2010 & 16.4 & $1.9 \pm 0.4$ & -9.76 & -69.5 & -11.1 & 41.2 & 7.5 & $<0.14$ & $\begin{array}{l}{ }^{14} \mathrm{C}=1.6 \mathrm{ka} \\
\text { holocene }\end{array}$ \\
\hline 24 & $\begin{array}{l}\text { Trutnowy } \\
\text { K/85-98 }\end{array}$ & $\begin{array}{l}1987 \\
2010 \\
\end{array}$ & $\begin{array}{l}25.8 \\
25.7\end{array}$ & & $\begin{array}{l}-10.1 \\
-9.99 \\
\end{array}$ & $\begin{array}{l}-67.0 \\
-72.6 \\
\end{array}$ & -6.4 & 7.0 & 2.4 & 0.70 & $\begin{array}{l}14 \mathrm{C}=11.8 \mathrm{ka} \\
\mathrm{H}+\mathrm{G}\end{array}$ \\
\hline 25 & $\begin{array}{l}\text { Krzywe K. } \\
\text { Q/10-26 }\end{array}$ & 2010 & 7.2 & $0.3 \pm 0.3$ & -9.75 & -69.3 & & & 7.5 & 0.21 & holocene \\
\hline
\end{tabular}

Uncertainty (standard deviation): $\delta^{18} \mathrm{O}- \pm 0.05 \%, \quad \delta \mathrm{D}- \pm 1 \%$, NGT (noble gas temperature) $- \pm 0.7^{\circ} \mathrm{C}$, ${ }^{4} \mathrm{He}$ excess $- \pm 10 \%$; Sampling points are shown in Fig. 1; Q - Quaternary, K - Cretaceous

The origin of the anomalously high concentrations of fluorine is connected with the leaching of fluoroferous minerals in the upper part of the Cretaceous strata and ion exchange and high $\mathrm{pH}>8$. The analysis of satellite pictures conducted by Daniel-Danielewska and others (1986) demonstrated the presence of cracking and tectonic discontinuities in the roof of the Cretaceous in the area of Żuławy and corroborated the existence of vertical geotectonic deformations occurring in the Holocene. The possibility is indicated both by the chemical composition of water at this level similar to water from the Cretaceous aquifer and the isotopic composition. Fig. 1 presents the location of salinity zones and places where fluoride anomalies have been found in the area of Żuławy Wiślane (Lidzbarski et al. 2007).

The results of the isotopic research as well as determinations of noble gases have confirmed that the oldest waters occur in the northern and central parts of Żuławyat the depth of just below 100 metres (Gozdawa, Kiezmark, Drewnica, Grochowo). These are mainly infiltrating waters in the cool climate of the late Pleistocene (the Vistula glaciation). The flow temperatures specified from the concentrations of noble gases (NGT) range from 0 to $3^{0} \mathrm{C}$. 
The values of stable isotopes' deltas are around $\delta^{18} \mathrm{O}=-12 \%$ and $\delta^{2} \mathrm{H}=-85 \%$, but there are here also waters the age of which based on ${ }^{14} \mathrm{C}$ parameters exceeds 12,000 years (tab. 1), and their isotopic compositions are similar to the waters of today's infiltration in this area $\left(\delta^{18} \mathrm{O}\right.$ $=-9.8 \%, \delta^{2} \mathrm{H}=-69 \%$ ). Zuber et al. (2000) claim that the isotopic compositions of these waters have undergone changes as a result of evaporation of surface water reservoirs before the process of infiltration and call them evaporated ,glacial" waters from the end of the last glaciation. They could also constitute infiltrating waters from the water-logged reservoirs on the pre-frontier of the ice sheet.

Slightly younger waters, the age of which ranges from 7,000 to 13,000 years, occur in water intakes at similar depths, but located closer to the edges of Lakeland plateaux (Roszkowo, Rachowo, Elbląg, Letniki, Malbork, Kościelniczki and Tczew). In shallower water intakes at depths 20-30 m, there occur waters which mainly originate from the Holocene infiltration.

In the central and northern parts of Żuławy, where hydraulic gradients are very low, $(i \rightarrow 0)$, zones of hindered water exchange as well as zones of stagnant water can be found. In such places the so-called young relict waters could survive until nowadays (Kozerski, Kwaterkiewicz 1984; Zuber et al. 2000) or at least the components of such waters mixed with waters of different origin, for example, contemporary or possibly earlier waters permeating to shallower aquifer levels as a result of ascension from the Mesozoic ground.

The decomposition of the Holocene organic matter in the deltaic series causes the emission of $\mathrm{CH}_{4}$ and $\mathrm{CO}_{2}$, observed in the wells in the village of Laszka, which prevents the correct interpretation of the age of water by means of the radiocarbon dating. The composition of stable isotopes in the water samples from Łaszki no. 11 and 12, which have revealed heavier isotopic compositions than waters of today's infiltration, indicates also the possibility of water admixtures from lakes, bayou or bays which no longer exist. The diagram of water circulation in this area is shown in fig. 3.

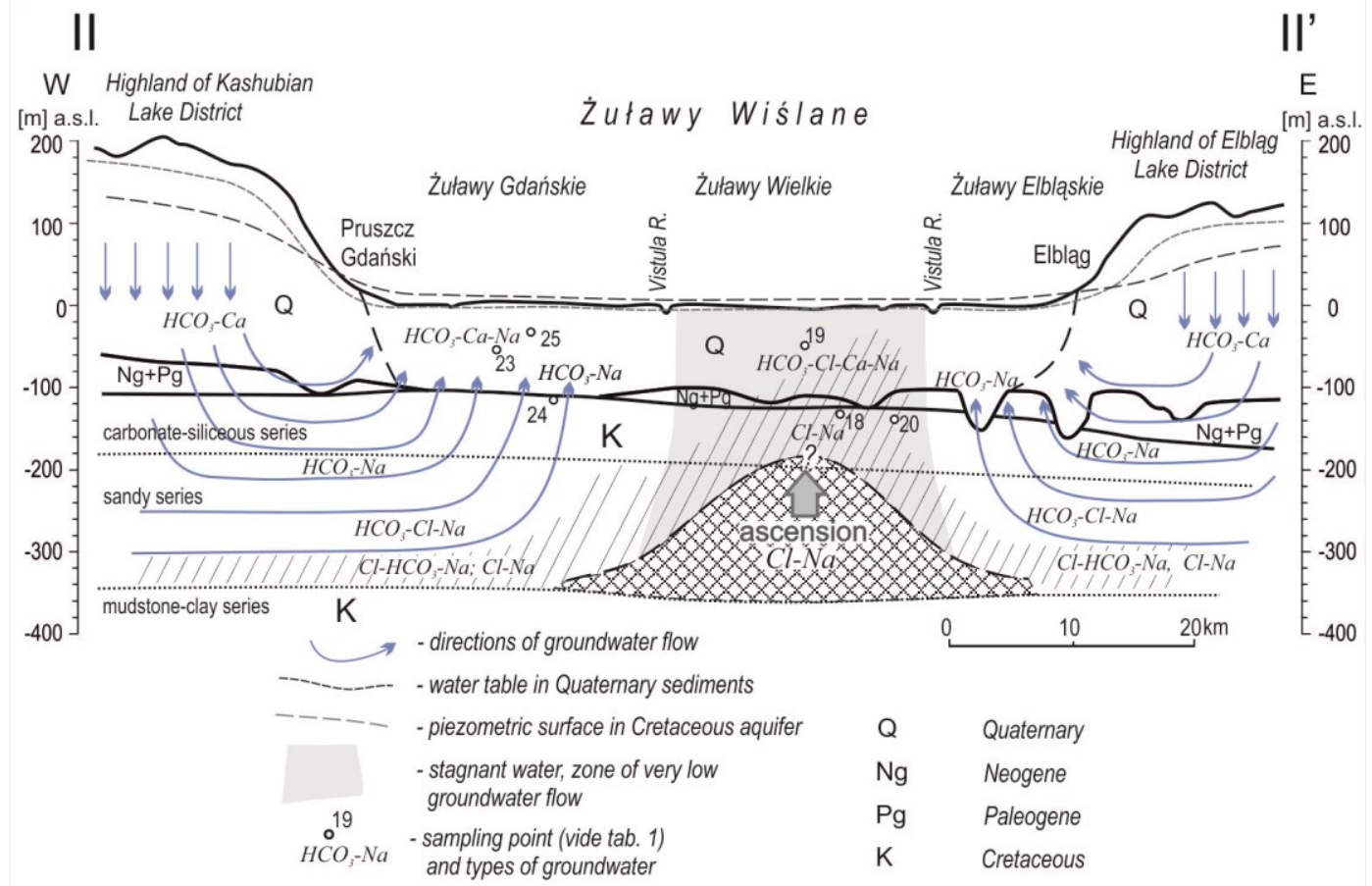

Figure 3. Schematic hydrochemical cross-section through the Żuławy Wiślane area (by Burzyński, and Sadurski 1989 modified by Krawiec 2013). 


\section{CONCLUSIONS}

The origin of the brackish waters of the deltaic series in the north-eastern part of Żuławy can be explained by the remains of the former Littorina Sea in the poorly permeable loamy and sandy sediments (Kozerski, Kwaterkiewicz 1984, 1988). The results of the most recent isotopic determinations and archive research findings (Zuber et al. 2000; Krawiec 2013) indicate the law content of ${ }^{14} \mathrm{C}$ in these waters, which would corroborate this hypothesis, simultaneously excluding the possibility of sea water intrusion.

\section{REFERENCES}

Burzyński, K. and A. Sadurski. 1989. Influence of near slop drainage of Lakeland plateau on the Cretaceous aquifer on the Vistula delta plane. [in polish, eng. Sum]. Kwart. Geol. t. 33 (2): 301-312.

Daniel-Danielska, B., S. Kibitlewski and A. Sadurski. 1986 - Geology of the Vistula delta plane and the satellite images. [in Polish, eng. sum]. Geol., t.30, 3/4: 643-658.

Kozerski, B. 1981. Salt water intrusions in to coastal aquifers of Gdansk region. Proc. 7th Salt Water Intrusion Meeting, Uppsala, (27): 83-89.

Kozerski, B. and A. Kwaterkiewicz. 1984. Zones of salinity of groundwater and its dynamics on the Vistula delta plane. [in polish, eng.sum]. Arch. Hydrotech., 31 (3): 231-255.

Kozerski, B. and Kwaterkiewicz A., 1988. The origin of groundwater salinity of Quaternary aquifer in the Gdańsk region. Proc. „Aktualne Problemy Hydrogeologii”. [in polish, eng. Sum]. Technical University of Gdańsk Publ. Gdańsk, vol. IV, part I: 93-104.

Kozerski, B., Maciaszczyk A., Pazdro Z. and Sadurski A., 1987. Fluorine anomaly in the groundwater in the Gdańsk Region. [in polish, eng. Sum.]. Ann. Soc. Geol. Pol., 57 (3-4): 349-374.

Krawiec, A. 2013. The origin of chloride anomalies in the groundwaters of the Polish Baltic coast. [in polish, eng.sum]. Nicholas Copernicus Univ. Publ.Toruń. pp. 1-143

Kulma, R., Haładus A., and Lidzbarski M,. 2002. Groundwater resources of the Vistula delta plane. [in polish, eng.sum.]. Polish Academy of Sciences. Gospodarka Surowcami Mineralnymi. 18, z. 2: $117-135$.

Lidzbarski, M. 2007. Region of lower Vistula. In: Regional hydrogeology of Poland. [in polish]. Paczyński B., Sadurski A., Edit. P.G.I. Publ., Warsaw.

Sadurski, A. 1985. Hydrogeochemical conditions of the Cretaceous aquifer in the Gdańsk area. [in polish, english sum.], Kwart. Geol., 29, 2: 405-418.

Sadurski, A. 1989. Upper Cretaceous groundwater system of Eastern Pomerania. [in polish, english sum.] Bull. of Geology Academy of Mining and Metallurgy Publ., Cracov : nr 46: 1-137.

Schroedter M., 1931. Die salzhaltigen grundwasser an der Weichselmundung. Geol. u. chem. Untersuchungen Danzig. Statist. Mitt.: 167. 
Zuber, A., Kozerski B., Sadurski A., Kwaterkiewicz A. and Grabczak J., 1990. Origin of brackish waters in the Quatemary aquifer of the Vistula delta. In: Proceed. of $11^{\text {th }}$ Salt Water Intrusion Meeting. Gdańsk: 249-262.

Zuber, A., Sadurski A., Weise S.M., Rübel A.,. Osenbrück K. and Grabczak J,. 2000. Isotope and noble gas data of the Gdańsk Cretaceous Aquifer, Northern Poland. In: Hydrogeology of the Coastal Aquifers. University of Nicholas Copernicus University Publ. pp. 181-186. 